\title{
STRATEGI PENGEMBANGAN AGILE KNOWLEDGE WORKER DI DIVISI FINANCE PT PFIZER INDONESIA BERDASARKAN PERSPEKTIF HUMAN CAPITAL DAN KNOWLEDGE MANAGEMENT
}

\author{
The Development Strategic of Agile Knowledge Worker in Finance Division \\ PT Pfizer Indonesia based on Human Capital and Knowledge Management \\ Perspectives
}

\section{Eva Fauziana}

Prodi Manajemen Institut Bisnis Muhammadiyah (IBM) Bekasi

Email: evafauziana8@gmail.com

Radical and global changes in the world and also the fast development of knowledge economy era (Drucker, 1990) affected and forced all profit and non-profit organizations to be radically adaptive to the changes. Pfizer Inc, as one of the biggest pharmaceutical corporation in the world, also aware the needs to be adaptive in the radical change. Led be new CEO, Mr. Jeffrey B. Kindler, Pfizer keeps on enhancing and improving itself by conducting Pfizer transformation since early 2006. For Pfizer People, transformation is not a short cut process of reduction costs and restructurization, but transformation are mainly focused to develop healthier and better environment in the world as stated in Pfizer new motto in 2016: "Working for Healthier World ${ }^{T M}$ " In finance division PT Pfizer Indonesia, the improvement and enhancement process are led by conducting Finance Survey in 2006. The survey becomes the basic evaluation and the key indicator as Finance Performance. From some theories on human capital compiled with other theories, references and understanding on knowledge management, change management, culture management, learning organization and agile leadership, I summarize the new concept of agile knowledge worker. I strongly support that the limitation of this new concept can be the new thoughts and ideas of the human capital and knowledge management development and implementation.

Keywords: Transformation, Human Capital, Knowledge Management, Agile Knowledge Worker

\section{PENDAHULUAN}

Perubahan bisnis di abad 21 ditandai dengan pesatnya globalisasi, informasi dan komunikasi. Keberagaman dunia yang terkotak-kotak dalam batas geografi dan budaya, akhirnya melebur dan terintegrasi dengan cepat melalui kekuatan informasi dan komunikasi. Peter Drucker menyebut abad 21 sebagai era knowledge society atau knowledge economy yang merepresentasikan revolusi dan transformasi di bidang industri (Willinsky, 2005).

Salah satu kunci sukses penunjang keberhasilan organisasi untuk beradaptasi di era knowledge economy ini adalah kemampuan organisasi untuk merespon dan mengimplementasikan perubahan dalam tubuh organisasi. Seberapa cepat dan seberapa efektif suatu organisasi mampu beradaptasi 
terhadap tekanan perubahan yang terjadi dalam lingkup eksternal maupun internal, akan menentukan sejauh mana organisasi mampu mencapai keberhasilannya (www.changemanagement.com).

Para pemimpin di Pfizer menyadari bahwa karyawan memainkan peran penting bagi keberhasilan transformasi di Pfizer. Karena itu karyawan harus menjadi agen perubahan di samping menjadi pengikut dan pelaksana perubahan itu sendiri.

Akan tetapi, sebagaimana terjadi pada setiap perubahan, proses transformasi menimbulkan resistensi. Sebelum menyiapkan orang-orang untuk dapat beradaptasi dengan mudah terhadap perubahan, sebaiknya para pemimpin memahami mengapa karyawan bersikap resisten terhadap perubahan.

Untuk mengantisipasi dai mengatasi resistensi yang timbul, manajemen dituntut untuk mampu mengembangkan suatu sistem sebagai suatu solusi yang terpadu. Hal inilah yang memicu dan mendorong penulis untuk menjadikan transformasi dan pengembangan knowledge workers di Pfizer sebagai materi bahasan dalam penulisan ini.

Dalam jurnal ini, penulis menekankan pada manajemen perubahan perilaku, ekspektasi karyawan serta kualitas kerja dan hubungan interpersonal pada seluruh karyawan di divisi Finance PT Pfizer Indonesia. Perubahan perilaku karyawan Finance tersebut juga dipacu dengan digunakannya alat bantu teknologi yang makin canggih, sehingga juga menuntut penguasaan teknis yang lebih tinggi dari masingmasing karyawan. Alat bantu teknologi yang canggih tersebut antara lain kemampuan penggunaan komputer dan penguasaan sistem keuangan yang lebih canggih, yang on-line satu dengan lainnya.

Adanya penggunaan

teknologi canggih ini membuat divisi Finance melakukan serangkaian perubahan, antara lain: perubahan struktur organisasi di Finance. Rotasi kerja antar departemen, promosi serta perubahan deskripsi tugas, serta pengembangan tugas dan tanggung jawab dari masingmasing staf juga dirancang sedemikian rupa demi mencapai tujuan transformasi di Pfizer.

Untuk menjalankan tiap fungsi dengan baik, dibutuhkan kesiapan sumber daya yang kompeten untuk menjalankan visi misi Finance sebagai divisi yang mendukung penuh aktivitas para pemangku kepentingan di Pfizer serta untuk mendukung pencapaian visi misi Pfizer secara global. Tanpa adanya dukungan sumber daya yang kompeten, divisi Finance hanya berfungsi sebagai divisi yang menjalankan aktivitas transfer keuangan dan pencatat keluar masuknya aliran kas saja.

Visi misi divisi Finance pada periode tersebut antara lain berkomitmen untuk menjadi partner bisnis terbaik bagi seluruh pemangku kepentingan di PT Pfizer Indonesia, dengan cara mengimplementasikan seluruh 
nilai luhur Pfizer di setiap aktivitas bisnis dan kehidupan sehari-hari. Divisi Finance juga berkomitmen untuk mencapai kualitas kinerja secara total dan menyeluruh di seluruh gugus tugas. Divisi Finance juga berkomitmen untuk menciptakan lingkungan kerja yang dapat memberikan inspirasi, menebarkan energi positif untuk mendukung terciptanya Indonesia yang lebih baik dan lebih sehat serta menjalankan organisasi berdasarkan proses belajar yang berkelanjutan.

Untuk mencapai visi dan misi tersebut, Finance telah melakukan beberapa terobosan baru antara lain mengadakan Finance Survey. Dalam survey ini penulis bertindak sebagai pendesain kuesioner berikut variabelnya, penghitung hail survey dibantu oleh staf dari Biro Statistik (BPS) serta bertindak sebagai penanggungjawab hasil survey dalam hal mengkomunikasikan hasil kepada seluruh tim Finance dan manajemen PT. Pfizer Indonesia. Tujuan utama dari survey ini adalah:

1. Melihat sejauh mana setiap karyawan memandang kinerja departemen dan divisinya

2. Memahami ekspektasi karyawan terhadap hubungan antara atasan, bawahan, rekan sekerja dan juga organisasi tempat bernaung.

3. Memahami ekspektasi karyawan atas pengembangan pribadinya antara lain dalam perluasan tanggungjawab, program pelatihan yang mendukung jenjang karir serta ekspektasi terhadap pengembangan karir di masa depan.

4. Mengukur tingkat keberhasilan Finance sebagai partner bisnis bagi para pemangku kepentingan, dalam hal ini divisi lain di luar Finance.

5. Sebagai cermin yang menjadi titik tolak ke arah perbaikan divisi, terutama sejak pergantian pimpinan divisi.

\section{Perumusan Masalah}

Dari uraian yang telah penulis jabarkan di atas, penulis menggarisbawahi beberapa permasalahan sebagai berikut:

1. Bagaimana merancang suatu program pengembangan karyawan yang sistematis berdasarkan perspektif human capital dan knowledge management menjadi "agile knowledge worker"?

2. Dampak psikologis apa yang akan timbul bila divisi Finance menerapkan pengembangan Agile Knowledge Worker dalam organisasinya? Bagaimana solusi yang akan diterapkan untuk mengatasi dampak tersebut?

3. Bagaimana menciptakan lingkungan kerja yang mendukung iklim belajar secara berkesinambungan (sustained learning organization) berdasarkan perspektif knowledge management?

\section{KERANGKA BERPIKIR}

Kesiapan sumber daya manusia yang tinggi dan solid, memberikan kontribusi utuh pada 
pencapaian kinerja organisasi melalui kapasitas intelektual yang dimiliki oleh tiap knowledge worker yang bekerja di perusahaan tersebut. Selain itu, organisasi dapat memberdayakan secara maksimal aspek social skills yang dimiliki oleh para knowledge worker untuk menjaga dan mengembangkan reputasi organisasi atau perusahaan.

Di sisi lain, organisasi juga harus dapat mengembangkan suatu sistem terpadu yang mampu meningkatkan dan mengembangkan kompetensi para karyawannya berdasarkan knowledge based serta mampu mengembangkan suatu sistem sehingga para knowledge worker tetap betah dan loyal berkerja dalam suatu organisasi,

Di era knowledge economy ini, organisasi membutuhkan manajemen sumber daya manusia yang mampu meningkatkan kompetensi dan kapabilitas organisasi secara menyeluruh. Hal tersebut dapat dilaksanakan antara lain dengan mendukung terciptanya knowledge creation, sharing dan diseminasi (penyebaran) knowledge. Hal tersebut dengan jelas digambarkan oleh Gloet (2003) pada peta hubungan antara Human Resources Management (HRM) dan Knowledge Management:

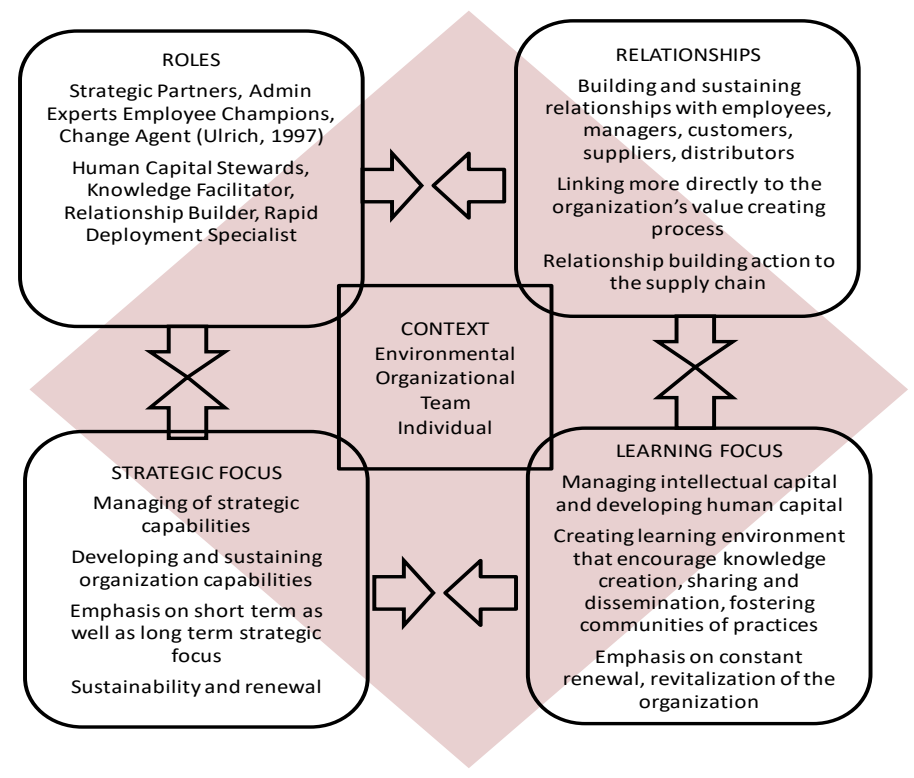

Gambar 1 Peta Hubungan antara KM \& HRM, Sumber: Gloet, 2004

\section{Human Capital \& Knowledge Management}

Pemahaman mengenai

Human Resources Management atau manajemen SDM merujuk pada pengertian seluruh strategi, kebijakan, peraturan, rencana, proses dan prosedur yang digunakan suatu organisasi untuk meningkatkan, mengatur dan 
mengembangkan sumber daya manusia, sehingga sumber daya manusia yang ada dapat memberikan kontribusi utuh terhadap kinerja suatu organisasi sehingga bisa menciptakan profit (HRM Journal, 2003).

HRM juga berfokus pada strategi pengembangan human capital dan bagaimana menciptakan sustained learning organization melalui Knowledge Management. Mac Donald (2003) dalam Gloet (2004) mengidentifikasi adanya hubungan antara pengembangan intellectual capital melalui program pengembangan karyawan yang antara lain berupa pengembangan kompetensi inti., kurikulum inti serta implementasi knowledge management sehingga memiliki nilai tambah bagi customer yang dilayani organisasi. Untuk

mengimplemenatsikan Knowledge Management dibutuhkan kesiapan HRM yang tinggi sehingga divisi HRD mampu menjadi katalisator yang menciptakan budaya dan iklim organisasi yang mendukung proses pembelajaran organisasi yang berkesinambungan. Adapun pemahaman mengenai budaya disarikan dari nilai-nilai luhur yang berada dalam suatu organisasi, yang merujuk kepada seluruh norma dan asumsi yang membimbing organisasi secara eksplisit dan implisit pada cara organisasi berpikir, berbuat, bertindak, atau keseluruhan cara bagaimana organisasi bersikap terhadap situasi dan kondisi yang ada (HRM Journal, 2003).

Adapun iklim organisasi merujuk pada pernyataan dalam organisasi yang menggambarkan kondisi internal organisasi dalam bagaimana hubungan antara organisasi dan anggotanya, antara satu divisi dengan divisi lainnya, antara atasan dan bawahan, antar departemen dalam satu divisi, serta antar individu yang ada dalam suatu organisasi sangat dipengaruhi oleh peran HRM dalam menciptakan hubungan antar anggota (HRM Journal, 2003). 


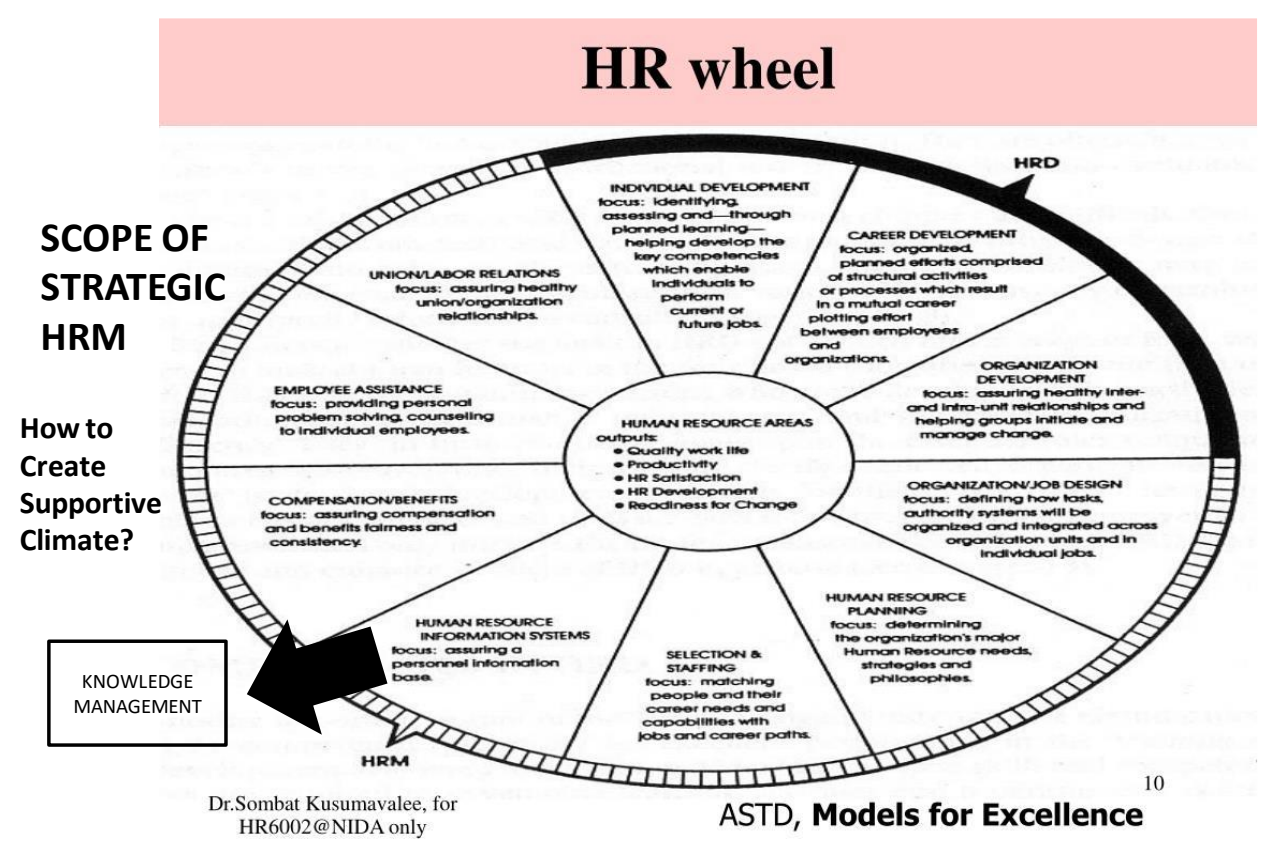

Gambar 2. Lingkup Strategic HRM, Sumber ASTD

Gambar di atas menunjukkan lingkup peran HRM terutama dalam menciptakan iklim yang mendukung implementasi knowledge management. Untuk itu, divisi HRD juga diharapkan mampu menjadi pemimpin dalam perubahan, dengan cara antara lain:

1. Manajemen perubahan selalu merujuk manusia sebagai subjek dan objek perubahan itu sendiri;

2. Memahami bahwa perubahan harus di mulai dari top manajemen dan dimulai pada hari pertama (day one) perubahan dicanangkan;

3. Memahami bahwa perubahan yang terjadi berbeda di setiap level dalam organisasi: manajemen, leaders, managers serta staf memiliki kontribusi serta peran berbeda dalam proses perubahan;

4. Dibutuhkan kepercayaan yang tinggi antara karyawan dan manajemen;

5. Menciptakan iklim bahwa proses perubahan menjadi proyek bersama seluruh karyawan, bukan hanya milik manajemen semata;

6. Membangun komunikasi terbuka atas strategi dan rencana organisasi untuk mensukseskan perubahan;

7. Menginformasikan sasaran perubahan serta persyaratan apa yang dibutuhkan dari manajemen kepada karyawan, sehingga karyawan memahami bagaimana bersikap dan 
memposisikan diri terhadap perubahan;

8. Selalu memperhatikan aspek dan pandangan masing-masing individu dalam organisasi, sehingga segala keluhan, ide dan saran mengenai proses perubahan dapat diakomodasi oleh manajemen;

9. Mempersiapkan organisasi terhadap segala konsekuensi dari proses perubahan yang ada, termasuk bagaimana mengatasi resistensi yang timbul dari karyawan terhadap proses tersebut (Booz Allen Hamilton, 2004).

Mengimplementasikan

knowledge management dengan cara menciptakan budaya knowledge sharing juga merupakan salah satu peran divisi HRD. Untuk mencapai kesuksesan menciptakan budaya knowledge sharing dalam organisasi, dibutuhkan beberapa faktor pendukung antara lain:

1. Manajemen bersikap proaktif dalam mendukung kinerja berbasis knowledge (knowledge based performance) serta menyediakan rekognisi yang adil dan seimbang bagi para high performer.

2. Secara berkala mengkomunikasikan perlunya knowledge sharing serta meminta top manajemen menjadi model dalam mengimplementasikan

budaya knowledge

sharing.

3. Mendukung setiap karyawan untuk melakukan knowledge sharing antara lain yang berhubungan dengan pengalaman, ilmu pengetahuan dan keahlian yang mereka miliki terhadap karyawan lainnya.

4. Menyediakan waktu bagi karyawan untuk menjalani proses belajar secara fleksibel baik belajar melalui pendidikan formal atau diskusi informal antar karyawan.

5. Mengimplementasikan knowledge management dalam kegiatan rutin operasional perusahaan, daripada melihat knowledge management sebagai sesuatu hal yang eksklusif dan terpisah dari kegiatan operasional bisnis sehari-hari. (Hariharan \& Bharti Infotel Group, 2002, dalam Daoust, 2004).

\section{Agility}

Dalam kamus New Webster's Encyclopedia edition (1998), Agile berarti: nimble, quick in action and movement. Dengan kata lain, agile berarti gesit, lincah, tangkas. Sedangkan agility merujuk pada ketangkasan, kecerdasan dan kelincahan seseorang, baik kelincahan fisik maupun kecerdasan intelektual. (Kamus Kontemporer Inggris Indonesia, Salim, 1999) 
Dalam jurnal Agility

International Briefing on Agility and Business Agility (Agility International $^{\odot}$ 2002) disebutkan bahwa agility mulai dikembangkan di Amerika Serikat karena terjadinya penurunan profit yang sangat mempengaruhi perekonomian dan sektor industry di Amerika. Dalam jurnal ini dijabarkan bahwa agility adalah strategi perusahaan untuk memberikan respon yang cepat terhadap perubahan bisnis yang amat radikal dan kompetitif. Kebutuhan akan adanya kemampuan agility berdasarkan empat prinsip utama, antara lain:

1. melayani pelanggan,

2. menguasai perubahan,

3. memobilisasi kompetensi serta sunber daya yang ada, dan

4. kemampuan untuk bersaing di industry, sehingga, agility menjadi tolak ukur penentu antara ketersediaan produk dan jasa yang ada dan dapat memenuhi kebutuhan pelanggan yang akhirnya dapat meningkatkan profit organisasi.

Dalam hubungannya dengan manajemen perubahan, agility bukanlah penentu arah perubahan, namun agility terkait erat dengan kemampuan dan kompetensi untuk bersaing serta menjadi pemenang dalam kompetisi tersebut. Lembaga Global Career Management telah melakukan survey untuk membuat daftar kompetensi tertinggi yang dibutuhkan oleh seorang pemimpin. Dari para responden yang berasal dari
130 senior eksekutif dan juga professional SDM yang bekerja di perusahaan yang termasuk dalam Fortune 500, ternyata disimpulkan bahwa ada tiga perangkat kompetensi tertinggi yang dibutuhkan dewasa ini:

1. Kemampuan menghasilkan profit,

2. Kemampuan mempengaruhi orang lain melalui kepemimpinan,

3. Agility (Lanigan, 2002).

Penulis menyimpulkan bahwa organisasi atau perusahaan mampu bertahan dan bersaing di era knowledge economy ini apabila perusahaan memiliki ketersediaan human capital yang memiliki kemampuan agility yang tinggi,

\section{Learning Organization}

Senge (1990) menyatakan bahwa learning organization adalah organisasi yang memiliki kapasitas untuk mampu menciptakan masa depannya sendiri. Learning organization sebagai sekumpulan individu dalam organisasi yang terus menerus memperbaiki kompetensi diri untuk menciptakan segala inovasi yang mampu mereka ciptakan (Maholtra, 1996).

Untuk itu, Senge (1990) menggarisbawahi bahwa learning organization yang sukses diindikasi dari adanya:

1. Proses pembelajaran individu yang berjalan dengan baik,

2. Proses knowledge sharing berjalan dengan baik,

3. Budaya perusahaan mendukung proses dan aktivitas pembelajaran,

4. Karyawan dimotivasi dan didukung penuh untuk mampu 
berpikir kritis dan berani mengambil resiko atas inovasi dan ide baru yang dijalankannya.

Senge (1990) berpendapat bahwa learning organization dapat berjalan dengan baik bila adanya kesiapan organisasi menjalankan kelima hal di bawah ini:

1. System thinking, seluruh aktivitas bisnis dilihat sebagai satu kesatuan yang utuh, di mana setiap aktivitas saling mempengaruhi. Bila satu system tidak berjalan dengan baik, hal tersebut juga akan mempengaruhi proses bisnis lainnya.

2. Personal mastery, setiap individu diharapkan mampu mendukung proses belajar dan aktivitas bisnis. Seluruh aktivitas bisnis dan kegiatan belajar disinergikan menjadi satu kekuatan utuh yang membawa organisasi meraih visi yang diharapkan.

3. Mental Models, proses belajar yang menggiring setiap individu dalam organisasi mampu berpikir secara efektif dan terbuka (open minded) sehingga juga mampu saling mempengaruhi dalam hal-hal yang bersifat positif.

4. Building shared vision, organisasi membangun visi yang sama akan masa depan, memvisualisasikan visi tersebut sehingga setiap aktivitas ditujukan untuk mencapai visi yang ditargetkan bersama.

5. Team Learning, setiap aktivitas bisnis dan proses belajar diproyeksikan sebagai kegiatan bersama untuk pencapaian satu tujuan.

Dari uraian di atas, penulis dapat menyimpulkan bahwa untuk mampu bertahan, bersaing dan beradaptasi terhadap perubahan dunis yang radikal dan persaingan pasar yang ketat, perusahaan harus memiliki kemampuan untuk terus menggali potensi individu dan organisasi. Dengan demikian, organisasi mampu menciptakan inovasi dan terobosan baru yang diimplementasikan dalam bisnis strategi yang handal. Hal tersebut dapat terwujud apabila organisasi mampu menciptakan iklim belajar dan knowledge sharing yang intens diantara para knowledge worker-nya.

\section{Agile Knowledge Worker}

Dari penjabaran teori dan konsep mengenai agility, learning organization,

human resources management serta knowledge management dan human capital di atas, penulis belum menemukan suatu teori spesifik mengenai agile knowledge worker.

Untuk itu, penulis menyimpulkan pengertian agile knowledge worker sebagai pekerja professional yang berada dalam suatu lembaga, baik profit maupun non-profit yang memiliki kemampuan beradaptasi terhadap perubahan. Kinerja dan kepemimpunannya mampu memberikan kontribusi terhadap organisasi, sehingga organisasi mampu memberikan pelayanan dan memenuhi kebutuhan konsumen dengan baik. 
Suatu organisasi dapat mengembangkan kualitas sumber daya manusianya menjadi agile knowledge worker bila organisasi memiliki sistem terstruktur yang mengintegrasikan antara sarana teknologi dengan kemampuan untuk belajar dan beradaptasi yang tinggi. Selain itu, organisasi harus memiliki kepercayaan penuh terhadap para karyawannya serta mendukung terciptanya lingkungan belajar yang berkelanjutan. Dalam hal ini, peran kepemimpinan menjadi penentu utama atas terciptanya organisasi yang memiliki agile knowledge worker.

Eksistensi agile knowledge worker dalam organisasi sangat ditentukan dari

awal, yakni sewaktu melakukan proses rekrutmen. Proses rekrutmen harus mampu menjaring sumber daya manusia yang memiliki potensi dan kemampuan yang tinggi, memiliki potensi untuk berkembang secara maksimal serta memiliki kemauan untuk belajar. Selanjutnya, kualitas agile knowledge worker juga ditentukan dengan adanya sistem pelatihan dan pengembangan yang sesuai dengan kebutuhan yang ada. Program tersebut diharapkan mampu menjembatani jarak antara kompetensi yang telah menjadi asset saat ini dengan kompetensi yang diharapkan baik kompetensi dari yang bersifat teknis dan nonteknis.

Agile knowledge worker juga berperan penting dalam terciptanya learning organization yang berkelanjutan, dengan mendukung penuh proses knowledge sharing session baik tacit maupun explicit knowledge sehingga perusahaan/organisasi memiliki kemampuan beradaptasi terhadap perubahan dan dapat memenangkan kompetisi dengan cara mampu memenuhi kebutuhan konsumen (customer focus oriented).

\section{METODE PENELITIAN}

Tulisan ini dibuat dengan tujuan untuk memberikan suatu alternatif rekomendasi kepada manajemen PT Pfizer Indonesia dalam menyusun dan mengimplementasikan sistem pengembangan "agile knowledge worker" khususnya di divisi Finance.

Di tahap awal penulisan, penulis menjabarkan kondisi human capital readiness di divisi Finance berdasarkan dua buah hasil survey yang penulis buat pada pertengahan Pebruari 2006. Hasil survey tersebut menjadi landasan utama penulis dalam merumuskan permasalahan yang ada untuk menyusun strategi yang akan penulis rekomendasikan bagi pengembangan human capital di divisi Finance.

Selanjutnya, pada bagian kerangka berpikir, penulis mendefinisikan kriteria "agile knowledge worker" di divisi Finance berdasarkan perspektif human capital, organizational learning dan knowledge management. Ulasan rinci dari pelaksanaan rekomendasi tersebut, dijabarkan pada bagian simpulan dan saran. 


\section{HASIL DAN PEMBAHASAN Responden}

Penulis

mencoba

menjabarkan kondisi saat itu di

divisi Finance dengan ekspektasi di masa depan, berdasarkan hasil survey yang telah dilakukan pada beberapa bulan sebelumnya. Survey tersebut dibagi menjadi dua bagian, yaitu:

1. Survey Internal

Responden terdiri dari 32 orang staf Finance, di level staf, supervisor, sampai dengan junior manager

2. Survey Eksternal

Total responden berjumlah 430 orang dari seluruh karyawan di seluruh divisi yang tersebar ke seluruh Indonesia. Divisi alin yang menjadi responden yaitu Marketing, Sales, HRD, Legal Affairs, Corporate Affairs, Business Technology, Research \& Development serta Manufacturing.

\section{Skala Pengukuran}

Menggunakan teori Two

Factors theory (Herzberg yang mengukur tingkat kepuasan karyawan pada faktor-faktor yang memotivasi mereka, antara lain:

1. Faktor Internal (Motivation Factors), yaitu kepuadan pada sistem pengembangan karyawan (advancement), jenis pekerjaan itu sendiri (job itself), pencapaian dalam pekerjaan (achievement) serta penghargaan yang mereka terima (recognition) atas kinerja yang telah mereka hasilkan.

2. Faktor Eksternal (Hygiene Factors), yaitu kepuasan karyawan terhadap cara atasan mensupervisi, serta hubungan baik dengan atasan, bawahan dan seluruh rekan kerja, antara lain:
a. Fokus pada pelanggan
b. Sistem pembayaran dan proses bisnis
c. Komunikasi

Dalam survey ini penulis tidak mengukur faktor gaji serta kondisi fisik lingkungan kerja yang juga sebenarnya menjadi bagian dari hygiene factors, sehingga yang dijadikan tolak ukur survey adalah faktor nonmaterial dan non-fisik.

Sebelum menyebarkan kuesioner, manajemen divisi Finance telah menggariskan tingkat kepuasan pada masingmasing survey yaitu minimal $75 \%$. Berarti tingkat kepuasan yang diharapkan dari seluruh karyawan Finance terhadap faktor-faktor penentu yang berupa motivator dan hygiene berada pada level $75 \%$.

Apabila hasil survey berada pada minimum $75 \%$ berarti faktor motivator dan faktor hygiene yang ada sudah memenuhi ekspektasi karyawan. Namun bila hasil survey tersebut berada di bawah level $75 \%$ berarti faktor penunjang: motivator dan hygiene masih perlu ditingkatkan lagi.

Untuk survey eksternal (responden di luar divisi Finance 
dalam lingkup Pfizer), manajemen menentukan tingkat kepuasan para pemangku kepentingan ada di level $70 \%$ dalam artian, tingkat kepuasan yang diharapkan dari para pemangku kepentingan internal terhadap pelayanan Finance minimum berada pada level $70 \%$. Bila hasil survey menunjukkan tingkat kepuasan berada pada level $70 \%$ atau lebih, berarti Finance telah memberikan pelayanan yang baik, dan para pemangku kepentingan internal merasa puas atas partnering dan pelayanan Finance selama ini. Bila hasil survey menunjukkan tingkat kepuasan di bawah $70 \%$, berarti divisi Finance harus berupaya penuh untuk melakukan perbaikan di segala bidang terutama pada area customer focus, sistem pembayaran dan proses bisnis serta komunikasi.

\section{Permasalahan dan Alternatif Solusi}

Meskipun hampir seluruh aspek dalam hasil kedua survey menunjukkan tingkat kepuasan antara $63 \%$ - $77 \%$ yang secara umum hampir mencapai kriteria kesuksesan $75 \%$, namun penulis melihat adanya aspesk-aspek yang perlu diperhatikan serta menjadi titik tolah perubahan yang bisa dilakukan demi meningtkatkan kinerja agile knowledge worker.

Divisi Finance di PT Pfizer Indonesia merupakan poin penting bagi kelancaran jalannya kegiatan operasional dan bisnis perusahaan juga sekaligus menjadi gate keeper bagi segala aktivitas bisnis operasional yang ada. Karena hampir seluruh kegiatan operasional bisnis membutuhkan dana dan dana perusahana dikelola oleh divisi Finance. Untuk itu, Finance harus selektif dan teliti dalam melakukan pengontrolan dan pelaporan keuangan, mendata seluruh asset perusahaan, menyusun stratejik perusahaan serta melakukan internal audit dan lain-lain.

Pentingnya peranan divisi Finance di PT Pfizer Indonesia dapat terlihat dalam jabaran deskripsi tugas tiap departemen yang ada yakni: (1) Controllership Department, (2) Treasury, (3) Planning \& Reporting, (4) Administrative (Citarasmi, 2007).

Menilik dari tugas, fungsi dan peranan yang diemban oleh divisi Finance di atas, penulis berpendapat bahwa divisi Finance memerlukan human capital readiness yang tinggi dari masing-masing agile knowledge worker di tiap departemen. Ketersediaan human capital readiness yang tinggi juga sejalan dengan general strategic objectives divisi Finance yang akan dicapai, antara lain: berkomitmen untuk menjadi partner bisnis terbaik bagi seluruh pemangku kepentingan di Pfizer Indonesia, dengan cara mengimplementasikan seluruh nilai luhur Pfizer di setiap aktivitas bisnis dan kehidupan sehari-hari. Berkomitmen untuk mencapai kualias kinerja secara total dan menyeluruh di seluruh area tugas. Divisi Finance juga berkomitmen untuk menciptakan lingkungan kerja yang dapat memberikan inspirasi menebarkan energi positif untuk mendukung 
terciptanya dunia yang lebih baik dan lebih sehat serta menjalankan organisasi berdasarkan proses belajar yang berkelanjutan (sustained learning organization).
Dari analisis permasalahan tersebut di atas, penulis menyimpulkan permasalahan serta alternatif solusi sebagai berikut:

\begin{tabular}{|c|c|}
\hline CURRENTSITUATION & INTENDEDSITUATION \\
\hline $\begin{array}{l}\text { Kebutuhan akan program } \\
\text { pengembangan yang spesifik }\end{array}$ & $\begin{array}{l}\text { Implementasi Individual } \\
\text { Development Program }\end{array}$ \\
\hline $\begin{array}{l}\text { Kebutuhan untuk meningkatkan } \\
\text { customer focus oriented }\end{array}$ & $\begin{array}{l}\text { Peningkatan kompetensi di seluruh } \\
\text { area }\end{array}$ \\
\hline $\begin{array}{l}\text { Kebutuhan untuk meningkatkan } \\
\text { kemampuan berkomunikasi }\end{array}$ & $\begin{array}{l}\text { kepemimpinan bagi seluruh } \\
\text { Finance Leaders }\end{array}$ \\
\hline
\end{tabular}

\section{ALTERNATIFSOLUSI}

-Mengembangkan performance management system

-Menentukan core competencies dan mengembangkan

core curricullum di Finance

-Menyiapkan program Learning \& Development yang

sesuai

-Mengembangkan budaya sharing di Finance

Gambar 3 Rangkuman Permasalahan dan Alternatif Solusi

\section{Rekomendasi Program}

Dari seluruh uraian tersebut di atas, penulis merekomendasikan langkah-langkah

yang harus disinergikan di tingkat organisasi (PT Pfizer Indonesia), di tingkat divisi (Finance) dan di tingkat individu (agile knowledge worker) di Finance, antara lain: 


\begin{tabular}{|c|c|c|}
\hline $\begin{array}{c}\text { Tingkat } \\
\text { Organisasi }\end{array}$ & Tingkat Divisi & Tingkat Individu \\
\hline $\begin{array}{l}\text { Mengembangkan } \\
\text { kriteria dan } \\
\text { karakteristik agile } \\
\text { knowledge worker } \\
\text { berikut } \\
\text { kompetensi inti } \\
\text { dan kurikulum inti } \\
\text { yang sesuai }\end{array}$ & $\begin{array}{l}\text { Mensosialisasikan } \\
\text { kriteria dan karakteristik } \\
\text { agile knowledge worker } \\
\text { berikut kompetensi inti } \\
\text { dan kurikulum inti di } \\
\text { setiap tim / departemen } \\
\text { yang ada }\end{array}$ & $\begin{array}{l}\text { Menyusun dan } \\
\text { menampilkan } \\
\text { kualitas kinerja } \\
\text { berdasarkan } \\
\text { kriteria dan } \\
\text { karakteristik agile } \\
\text { knowledge worker } \\
\text { sesuai dengan } \\
\text { kompetensi inti } \\
\text { dan kurikulum inti }\end{array}$ \\
\hline $\begin{array}{l}\text { Mengembangkan } \\
\text { performance } \\
\text { management } \\
\text { system }\end{array}$ & $\begin{array}{l}\text { Mengembangkan } \\
\text { seluruh manager/leader } \\
\text { sehingga mampu } \\
\text { mengimplementasikan } \\
\text { performance } \\
\text { management system di } \\
\text { divisnya masing-masing }\end{array}$ & $\begin{array}{l}\text { Menyusun dan } \\
\text { menampilkan } \\
\text { kualitas kinerja } \\
\text { berdasarkan } \\
\text { performance } \\
\text { management } \\
\text { system }\end{array}$ \\
\hline $\begin{array}{l}\text { Menyusun } \\
\text { program pelatihan } \\
\text { dan } \\
\text { pengembangan } \\
\text { yang sesuai } \\
\text { dengan } \\
\text { kompetensi yang } \\
\text { dibutuhkan }\end{array}$ & $\begin{array}{l}\text { Mendefinisikan detail } \\
\text { kompetensi yang } \\
\text { dibutuhkan }\end{array}$ & $\begin{array}{l}\text { Menyusun dan } \\
\text { menampilan } \\
\text { kualitas kinerjanya }\end{array}$ \\
\hline $\begin{array}{l}\text { Organizational } \\
\text { learning }\end{array}$ & $\begin{array}{l}\text { Menciptakan lingkungan } \\
\text { yang mendukung iklim } \\
\text { belajar }\end{array}$ & $\begin{array}{l}\text { Menjadikan } \\
\text { kegiatan belajar } \\
\text { merupakan } \\
\text { kebiasaan / habit }\end{array}$ \\
\hline
\end{tabular}




$\begin{array}{lrrr}\text { Dari uraian yang penulis } & \text { kriteria dan karakteristik agile } \\ \text { telah jabarkan sebelumnya, } & \text { knowledge worker di divisi } \\ \text { penulis } & \text { merekomendasikan } & \text { Finance sebagai berikut: }\end{array}$

\begin{tabular}{|c|c|c|}
\hline No & Kriteria \& Karakteristik & Uraian \\
\hline 1 & $\begin{array}{ll}\text { Perspektif Bisnis dan } \\
\text { Prospek Bisnis }\end{array}$ & $\begin{array}{ll}\text { - } & \text { Management Project Skills } \\
\text { - } & \text { Management Orientation } \\
\text { - } & \text { Perencanaan, } \\
& \text { Pengorganisasian, } \\
& \text { Monitoring, Standar kualitas, } \\
\text { - } & \text { Orientasi pada pelanggan } \\
\text { - } & \text { Problem solving } \\
\text { - } & \text { Pemahaman akan dinamika } \\
& \text { organisasi } \\
\text { - } \quad \text { Berorientasi pada tujuan/hasil }\end{array}$ \\
\hline 2 & - Komunikasi & $\begin{array}{ll}\text { - } & \text { Kemampuan komunikasi di } \\
\text { - } & \text { bidang lisan dan tulisan } \\
\text { - } & \text { Meeting Skills } \\
\text { - } & \text { Public presentation } \\
\text { - } & \text { Interpersonal skills }\end{array}$ \\
\hline 3 & - People Skills & $\begin{array}{l}\text { - } \text { Team skills } \\
\text { - Leadership skills dan } \\
\text { Followership skills } \\
\text { - Interpersonal skills / } \\
\text { relationship building }\end{array}$ \\
\hline 4 & - Personal Skills & $\begin{array}{ll}\text { - } & \text { Profesionalisasi } \\
\text { - } & \text { Strategic Thinking skills } \\
\text { - } & \text { Multi tasking skills } \\
\text { - } & \text { Time Management } \\
\text { - } & \text { Stress Management } \\
\text { - } & \text { Ressilience } \\
\text { - } & \text { Innitiative } \\
\text { - } & \text { Motivation }\end{array}$ \\
\hline
\end{tabular}

Gambar 5 telah diolah dari berbagai sumber

Penjabaran detail dari table tersebut di atas, penulis rekomendasikan berikut ini:

1. Kompetensi Inti

2. Kurikulum Inti

3. Jenjang Karir
4. Performance Management System

5. Program Pelatihan dan Pengembangan Karyawan

6. Knowledge Management sebagai Implementasi dari Organizational Learning 


\section{Kendala Pelaksanaan}

Ada beberapa kendala yang mungkin akan dihadapi apabila organisasi melakukan knowledge sharing, antara lain: struktur organisasi, manajemen serta para karyawan itu sendiri. Penulis ingin member masukan kepada manajemen PT Pfizer Indonesia mengenai beberapa kendala yang mungkin dihadapi dalam mengimplementasikan knowledge management:

1. Kurangnya rasa percaya antar anggota tim

2. Kebutuhan anggota tidak diperhatikan

3. Kontrol yang terlalu ketat serta adanya perubahan besarnya struktur organisasi, gaya kepemimpinan serta frekuensi jadwal pertemuan yang makin meningkat. Poin penting dalam hal ini adalah bahwa partisipasi di dalam implementasi ini hendaknya bersifat voluntir dan bukanlah sesuatu yang harus dipaksakan. Knowledge sharing hendaknya dijadikan community of practice yang telah melembaga. Keberhasilan internalisasi proses knowledge sharing dapat berjalan dengan baik bila ada sistem penghargaan yang diberikan bila para agile knowledge worker mampu melakukan proses sharing ini.

4. Kegiatan yang ada kurang fokus dan tidak berhubungan dengan bisnis yang dijalankan perusahaan.

5. Kurang sumber daya yang memadai serta kurangnya dukungan dari senior manajemen.

6. Kurang mendapat penghargaan dari senior manajemen atas semua pencapaian yang telah dilakukan.

Critical Success Factor dan Key Success Factor

Untuk terciptanya keberhasilan atas pengimplementasian agile knowledge worker di divisi Finance, penulis merekomendasikan beberapa kriteria sebagai berikut:

1. Critical Success Factors Menyelenggarakan Finance Survey di akhir tahun berikutnya dengan format yang sama untuk mencapai tingkat kepuasan pada level $80 \%$

2. Key Success Factors

○ Dukungan penuh dari manajemen

- Dukungan dan kerjasama dengan divisi HRD terutama dalam pengembangan sistem baru serta evaluasi atas penerapan sistem tersebut.

- Dukungan penuh dari seluruh Finance Leaders baik secara moral maupun tindakan nyata

- Kemauan dan motivasi yang kuat dari seluruh agile knowledge worker di Finace

\section{SIMPULAN DAN SARAN}

Divisi HRD diharapkan mampu melakukan SWOT analysis atas kendala yang ada serta mampu bekerjasama dengan manajemen untuk mengelola 
seluruh aspek yang ada sehingga proses transformasi yang dilakukan dalam organisasi mampu bersinergi secara utuh demi suksesnya pencapaian tujuan sesuai visi msi bersama.

Dari rekomendasi yang telah penulisuraikan, penulis juga menyarankan kepada manajemen, terutama divisi HRD untuk menciptakan succession planning dan talent management yang mampu merekrut, mengembangkan dan mempertahankan para agile knowledge worker di divisi Finance.

Terciptanya sistem rewards dan recognition yang seimbang, antara worker juga menjadi faktor penentu kesuksesan program ini. Reward dan recognition bukanlah berupa penghargaan materi/finansial semata, namun perhatian dari manajemen pada agile knowledge worker ini berupa morale rewards juga dapat meningkatkan motivasi para agile knowledge worker. Morale rewards tersebut dapat berupa pujian langsung setelah pencapaian kinerja secara lisan atau tertulis, dipercaya untuk memimpin suatu project baru, diikutsertakan dalam pelatihan/rapat yang diselenggarakan di region (negara) lain untuk menambah wawasan, mempresentasikan knowledge baru yang ia kuasasi atau project yang telah ia selesaikan dengan sukses sampai dengan promosi ke jenjang karir yang lebih tinggi.

Selain itu penulis juga ingin memberikan beberapa pandangan kepada Divisi HRD dan manajemen PT Pfizer Indonesia, langkah-langkah yang bisa diambil untuk mengatasi resistensi yang mungkin timbul dalam penerapan sistem ini secara keseluruhan:

\begin{tabular}{|c|c|c|}
\hline No & $\begin{array}{c}\text { Resistensi Yang Mungkin } \\
\text { Timbul }\end{array}$ & Alternatif Rekomendsasi \\
\hline 1 & $\begin{array}{l}\text { Persepsi dan pengalaman masing- } \\
\text { masing individu tentang } \\
\text { perubahan itu sendiri }\end{array}$ & 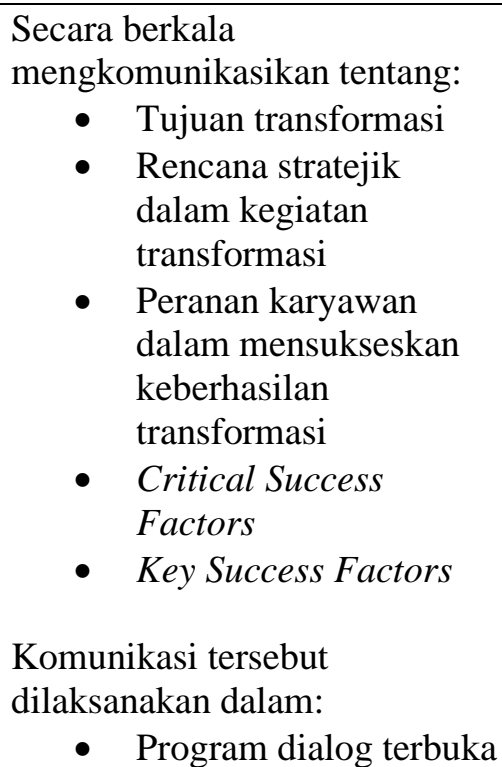 \\
\hline
\end{tabular}




\begin{tabular}{|c|c|c|}
\hline & & $\begin{array}{l}\text { Komunikasi dari top } \\
\text { management yang } \\
\text { dikirim via email }\end{array}$ \\
\hline 2 & $\begin{array}{l}\text { Takut akan kejutan dan sesuatu } \\
\text { hal yang belum pasti }\end{array}$ & Idem \\
\hline 3 & $\begin{array}{l}\text { Iklim saling tidak percaya yang } \\
\text { kental di dalam organisasi }\end{array}$ & $\begin{array}{ll}\text { Forum dialog antar } \\
\text { divisi } \\
\text { Company Gathering } \\
\text { seperti Sport Day, } \\
\text { Perayaan Hari Besar } \\
\text { Kenegaraan yang } \\
\text { diperingati secara } \\
\text { bersama untuk } \\
\text { meningkatkan } \\
\text { kerukunan dan } \\
\text { kekompakan antar } \\
\text { divisi }\end{array}$ \\
\hline 4 & Takut gagal & $\begin{array}{l}\text { Coaching dan mentoring dari } \\
\text { atasan masing-masing }\end{array}$ \\
\hline 5 & $\begin{array}{l}\text { Takut kehilangan posisi dan takut } \\
\text { kehilangan rasa nyaman }\end{array}$ & $\begin{array}{l}\text { Dari awal manajemen } \\
\text { mengkomunikasikan criteria } \\
\text { success factors dan key } \\
\text { success factors serta kriteria } \\
\text { karyawan yang seperti apa } \\
\text { yang diharapkan manajemen } \\
\text { untuk mewujudkan } \\
\text { keberhasilan transformasi }\end{array}$ \\
\hline 6 & Tekanan dari rekan kerja & Memperkuat kerjasama tim \\
\hline 7 & $\begin{array}{l}\text { Gangguan yang diakibatkan oleh } \\
\text { tradisi/budaya yang ada yang } \\
\text { sudah mengakar di organisasi }\end{array}$ & $\begin{array}{l}\text { Program sosialisasi, } \\
\text { komunikasi serta internalisasi } \\
\text { yang berkala }\end{array}$ \\
\hline 8 & Konflik personal & $\begin{array}{l}\text { Penyelesaian konflik yang } \\
\text { melibatkan orang-orang } \\
\text { terpercaya yang berada pada } \\
\text { posisi netral yang dianggap } \\
\text { mampu menyelesaikan konflik } \\
\text { serta mendamaikannya }\end{array}$ \\
\hline 9 & $\begin{array}{l}\text { Kurangnya strategi yang sesuai } \\
\text { dan waktu yang tepat }\end{array}$ & $\begin{array}{l}\text { Pematangan strategi sebelum } \\
\text { strategi transformasi } \\
\text { dikomunikasikan pada seluruh } \\
\text { karyawan }\end{array}$ \\
\hline 10 & $\begin{array}{l}\text { Tidak melihat keuntungan } \\
\text { perubahan bagi dirinya sendiri }\end{array}$ & $\begin{array}{l}\text { Coaching dan } \\
\text { mentoring dari masing- } \\
\text { masing leader } \\
\text { - } \quad \begin{array}{l}\text { Dialog terbuka akan } \\
\text { manfaat transformasi }\end{array}\end{array}$ \\
\hline
\end{tabular}




\section{DAFTAR PUSTAKA}

Agndal, H \& Nilsson U (2006). Generation of human and structural capital: Lessons from knowledge management. Electronic Journal of Knowledge Management. Vol. 4 - February

Agility International Briefing on agility and business agility. (2002) Agility International Journal@ Vol. July

Berard, V. (2003) Misconceptions of the agile zealots. United States: The Object Agency, LLC

Berger, A \& Berger, R (2004) The Talent Management Hand Book, Creating Organizational excellence by identifiying, developing and promoting your best people. USA: Mc Graw Hill

Booz, Allen Hamilton (2004). Ten guiding principles of change management. USA: Booz Allen Hamilton. Journal August Ed.

Burton, M (1999). Tension resistance to change in organizational climate: Managerial implications for a pace world. Denmark.

Guiding organization through transition. Change Management Journal: http://www.dod/mil/comptroller/i center/learn/changemangement/ht ml. April 2006

Change Management: Best Practice White Paper, Cisco System. 2002 Ed.

Citarasmi B. (2007). Presentation materials used in Pfizer Indonesia. Indonesia: Jakarta
Collins, Jim (2001). Good to Great, USA: Harper Business

Conway, S. \& Sligar, C. (2002).

Knowledge Management-unclocking knowledge assetssolution from Microsoft. Redmond: Microsoft Press

Cooper, Robert G. (2001) Winning at new products accelerating the process from idea to launch. New York: Basic Book

Daoust B. (2004). Corporate Culture and Knowledge Management. www.bizmechanicx.com

Davis, S. (2002). The top 10 steps to make major life changes. Journal Change Management Vol. 6. Dec 2002.

DeNisi, A. et al. (2001) The knowledge based approach to sustainable competitive advantage. Journal Vol. March 2001

Drucker, P. (1999). Knowledge Economy - Journal Knowledge Economy

Dooley, J (1998). Cultural Aspects of Systemic Change Mangement

Dunn, S (2003). The 10 ways to become change proficient. USA: Coach Ville

Senge, P (1990). The fifth discipline, the art \& practice of learning organization, USA: Currency doubleday.

Senge, P. et al. (2004). Presence - an exploration of profound change in people, organizations and society. USA: Currency Doubleday 